\title{
TUDOMÁNYKOMMUNIKÁCIÓ AZ „IGAZSÁGON TÚLI” VILÁGÁBAN
}

\section{COMMUNICATING SCIENTIFIC RESULTS IN A 'POST-TRUTH' ERA}

\author{
Rédey Soma \\ PhD-doktorjelölt, Eötvös Loránd Tudományegyetem Filozófiatudományi Doktori Iskola, Budapest \\ főosztályvezető-helyettes, MTA Titkárság Kommunikációs Főosztály, Budapest \\ redeysoma@gmail.com
}

\begin{abstract}
ÖSSZEFOGLALÁS
Dolgozatommal arra a jelenségre kívánom felhívni a figyelmet, melyet az „igazságon túli” (posttruth) tények megjelenése jelent a tudományos diskurzusban. Jóllehet a meghatározást többnyire politikai témákkal kapcsolatban használják, álhírek formájában megjelenik különböző tudományos vonatkozású területeken is: gondoljunk csak a klímaváltozással, az oltásokkal vagy az evolúcióval kapcsolatos kérdésekre. A legnagyobb veszély, amelyet az álhírek e területen való elterjedése jelent, hogy a tudományos tények tagadásához vezethet. Mi áll az „alternatív tények" gyors terjedésének hátterében, miért hiszik el tömegek a korábban tudományosan bizonyított állítások ellenkezőjét? Milyen megoldást kínálhatnak a különböző tudománykommunikációs modellek erre a jelenségre?

A nyílt tudomány (open science) mint tudománymódszertani megközelítés olyan hátteret jelenthet a tudományos közösség számára, mely segíthet az "igazságon túli" tények kezelésében. A tudományos kutatás első fázisában keletkező eredmények elérhetővé tétele közelebb hozhatja az érdeklődőket a tudományhoz. Sőt, adott esetben akár lehetőséget biztosíthat a tudományon kívüli közösségnek, hogy közremúködjön a tudományos eredmények létrehozásában. A fentieket a közösségi média kontextusában is érdemes vizsgálni. Hol vannak a közösségi média kínálta lehetőségek határai, mennyiben előnyös a használata a tudomány számára?

Az online és interaktív kommunikációs csatornák megjelenésével és térhódításával megváltoztak a tudománykommunikációs módszerek. A közösségi média jelentős szerepet játszik az úgynevezett "párbeszédmodell” (dialogue model) elterjedésében, melyben a tudomány iránti elkötelezettség (public engagement with science) kap kiemelt hangsúlyt. Ez a kezdeményezés segíthet eligazodni abban az információs rengetegben, melyben a tudományos tények felismerhetetlenné válhatnak.
\end{abstract}

A dolgozatom végén egy esettanulmányban bemutatok egy példát az „igazságon túli” környezet kezelésére.

\section{ABSTRACT}

What does 'post-truth' means in terms of scientific issues? This phenomenon is mostly related to the political sphere, though it has significant relevance with regard to science-related issues such as climate change, vaccination or evolutionary questions. This paper is an attempt to investigate this topic, in which the most important question is whether the 'post-truth' phenomenon can lead to a denial of scientific facts. If the answer is affirmative, we must ask what the reason 
is for the belief in 'alternative facts', and why there is a relatively high number of people who subscribe to them. What kind of solutions can science communication models offer?

It is my view that Open Science should give scientists a background which can help in the management of the 'post-truth' phenomenon. Sharing scientific information in the very early phases of scientific processes can bring interested lay people closer to science. Indeed, there is even an opportunity for non-scientists to contribute to the attainment of scientific results. I also investigate the role of social media in this context. What are the limits of the useful and advantageous use of social media on the part of scientists?

Among scholars there is agreement that with the ever-growing role of online and interactive media channels, science communication methods have changed. Social media plays a significant role in the new 'dialogue model' in which its role of 'public engagement with science' is emphasized. This initiative can provide further help in terms of navigation in the information mass, where real scientific facts can still remain unrecognizable.

Finally, I provide a case study as an institutional best practice to manage the problem in the post-truth environment.

Kulcsszavak: tudománykommunikáció, közösségi média, nyílt tudomány, igazságon túli tudomány

Keywords: science communication, social media, open science, post-truth science

\section{BEVEZETÉS}

„Az alternatív tények használata egyszerü hazugság” - mondta Rolf-Dieter Heuer, az Európai Bizottság tudományos tanácsadó testületének elnöke, a CERN korábbi főigazgatója 2017 novemberében Jordániában a World Science Forum Tudományalapú tanácsadás a politikusoknak címủ tematikus ülésén (Heuer, 2017).

Az elmúlt években számos tudományos fórum foglalkozott az álhírekkel és a tudománykommunikációra tett jelentős hatásukkal. Hogyan juthattunk el a jelenlegi helyzetig, és milyen megoldásokat lehet találni a kezelésére? Segíthet eligazodni, ha megnézzük a nyílt tudomány (open science) kínálta lehetőségeket.

Michael Nielsen (2011) szerint a nyílt tudomány esetében a tudományos tudás azt jelenti, hogy az információ szabadon elérhető mind a tudományos közösség tagjai, mind a laikus érdeklődők számára már a kutatás korai fázisában. Ezt a felfogást a tudósok egy bizonyos köre elfogadta, és fel is ismerte a benne rejlö lehetőségeket. A tudományos tények terjedése ráadásul a közösségi média egyre aktívabb használata miatt egyre gyorsabb. A legfrissebb felmérések szerint (McIntyre, 2018) a lakosság elsődleges forrása a tudományos és technológiai információt illetően az internet (a korábbi években jellemző nyomtatott és elektronikus médiával szemben). A tudósok maguk is egyre aktívabbak a közösségi médiában, ez a jelenség ösztönözte az ún. „Kardashian-index” bevezetését, amely 
a kutatók tudományos aktivitásának és a közösségi médiában való jelenlétének arányát mutatja (Hall, 2014). A fent említett jelenségek azonban számos bizonytalansági tényezőt hordoznak magukban. A jelenség alapvetően két szempontból közelíthető meg. Egyrészt az információt közlő szereplő és a közölt tudományos tény oldaláról. Beszélhetünk-e a tudomány természetének megváltozásáról (a „,normál” tudományról „posztnormálra” való váltásról)? Vajon mik a lehetőségeik, és mi a tudósok felelössége a közösségi médiában való részvételük során? A nyílt tudomány felfogásának terjedése hatással van a tudománykommunikáció filozófiájára is. Az eddigi deficitjellegü tudománykommunikációs modellt felváltja a tudományban való részvétellel történő megértés modellje. Másrészt vizsgálható a jelenség a befogadó (a kommunikációs folyamatban részt vevő további szereplők) oldaláról: milyen információkkal találkoznak, ezeket honnan szerzik, és mire használják fel. Dolgozatomban kitérek továbbá olyan szempontokra is, amelyek segíthetnek kezelni a keletkező problémákat.

\section{A „POST-TRUTH", VAGYIS AZ „IGAZSÁGON TÚLI" TUDOMÁNY}

Az „igazságon túli” kifejezés jelentőségét mutatja, hogy 2016-ban az Oxford Dictionary az év szavának választotta (Oxford, 2016). A szerkesztők definíciója szerint a kifejezést olyan esetben használják, amikor az objektív tények helyett inkább az érzelmek és a személyes meggyőződés befolyásolja a közvélemény alakulását. Lee McIntyre (2018) meghatározása szerint az ,igazságon túli” környezettel nem az a probléma, hogy tagadja az objektív tényeket, hanem az, hogy torzul a kommunikációs folyamat, mert hitelesnek és megbízhatónak tűnő tényeket használnak fel arra, hogy szándékosan alakítsák az olvasó véleményét. Ez emlékeztet a szándékos tudatlanság (willful ignorance) jelenségére, amikor nem tudjuk, hogy egy információ helyes-e vagy sem, mégis beszélünk róla, és helytállóságának ellenőrzése nélkül hivatkozunk is rá.

$\mathrm{Az}$,igazságon túli” jelenség hasonló a hazugsághoz: úgy állítunk tényeket, hogy tudjuk róluk, hogy valótlanok. Tehát egyszerủen a közönség manipulációjáról van szó. Jóllehet az ,igazságon túli” kifejezést többnyire a politikai vonatkozású szövegekkel kapcsolatban használják, jelen tanulmányban a tudományos területekre vonatkozó hatásaival foglalkozom. Gondoljunk csak a klímaváltozással, az oltásokkal vagy az evolúciós teóriákkal kapcsolatos félretájékoztatásra és e tanok egyre intenzívebb terjedésére, melyek mind összefüggésben vannak az „igazságon túli” jelenségével. Ha olyan szakterületről származó információval találkozunk, amelyben nem vagyunk járatosak, akkor a félretájékoztatás következtében elöször megkérdőjelezzük, majd akár meg is tagadjuk a korábban tudományosan bizonyított tényeket. Ezt pedig azzal támasztjuk alá saját magunk igazolására, hogy a kutatókról azt feltételezzük, elfogultak a saját elméletük iránt. 
McIntyre (2018) szerint az igazságon túli jelenség erősödését három fö tényező befolyásolja. Az első a kognitiv torzulás (cognitive biases), mely a vélemény megváltoztatásával és a tényekben való hit személyes motivációjával van összefüggésben. McIntyre kiemeli a „,visszaütés” (backfire effect) és a „motivált érvelés" (motivated reasoning) jelenségét, mikor egy hiteles bizonyíték akár tovább erősítheti a tévhitet. Kognitív torzulás figyelhető meg akkor is, amikor például elvakultan szurkolunk egy csapatnak, és nem veszünk tudomást a gyengeségeiről és a hibáiról. Szintén erre a jelenségre vezethető vissza az ún. „interaktív csoportjelenség" (interactive group effect), amikor az interaktív résztvevők szava erősebb a passzívakénál.

Második tényezőként említi McIntyre a hagyományos média - a klasszikus nyomtatott sajtó és az elektronikus média - visszaszorulását, ami egybeesik a harmadikkal, a közösségi média egyre erősödő térhóditásával. Az eredetileg egyirányú információfolyamban a média az igazat közölte, a közönség pedig ezt elhitte. Ezzel szemben a közösségi média világában az információ szabadon áramlik, mindenki eldöntheti, hogy miben kíván hinni. McIntyre felhívja a figyelmet a Facebook mint információforrás egyre nagyobb szerepére és a benne rejlő veszélyekre. A Facebookon megjelenő hírekkel kapcsolatban az a legfőbb probléma, hogy az olvasó csak az általa preferált szempontok szerint jut információhoz, és a „szürőbuborékon” (filter bubble) kívül más hír vagy információ nem jut el hozzá (lásd még: Pariser, 2011; Zuiderveen Borgesius et al., 2016). Az ,igazságon túli” kifejezést gyakran hozzák összefüggésbe megjelenési formájával, az álhírekkel. Ebben gyakran említik az online hírtartalmak „kapuörei” (gatekeepers), a szerkesztők felelősségét, akik a címre kattintások számának növelésében érdekeltek. A kattintásvadász (clickbait) tartalmak megjelenése és terjedése hozzájárult a félrevezető tájékoztatás megerősödéséhez az online médiában (Chen et al., 2015).

A fent említettek alátámasztják azt a tényt, hogy az ,igazságon túli” jelensége elsősorban az érzelmeinkre és a hitünkre van hatással. Michael Lynch (2017) szimmetriaelméletében (symmetry concept) a tény és az igazság definíciójával foglalkozik. Felteszi a kérdést, hogyan lehetséges összehasonlítani és egymással szembeállítani az objektív tényeket, valamint az érzelmeken és hiedelmeken alapuló tájékoztatást. Sergio Sismondo (2017) arra a kérdésre keresi a választ, vajon már elkezdődött-e az ,igazságon túli” korszak, vagy sem. Mennyiben befolyásolja a kérdést, hogy akár egy Twitter-felhasználói jogosultság is elegendő ahhoz, hogy tudást közvetítsünk? Fordítunk-e elegendő figyelmet arra, hogy ezekben az esetekben megkülönböztessük a valódit az álinformációtól? A befogadói közönségre úgy tekintünk-e, mint akit befolyásolni vagy meggyőzni kell? A fenti kérdések további vizsgálata szükséges ahhoz, hogy közelebb kerüljünk a probléma megoldásához.

A nyílt tudomány hatékony segítséget nyújthat a félretájékoztatás elleni küzdelemben, hiszen legfőbb célja az információ és a tudományos eredmények megosztása, nemcsak a tudósokkal, hanem a tudomány iránt érdeklődő laikusokkal is. 


\section{NYÍLT TUDOMÁNY}

Alessandro Delfanti egy konferencián (Open Science Summit, 2010) a kaliforniai Berkeley Egyetemen úgy fogalmazott, hogy a tudománynak mindenki számára elérhetőnek kell lennie, és nem szabad korlátozni szabadalmakkal és védjegyoltalmakkal.

A nyílt tudomány első forradalma a 17-18. században zajlott (Nielsen, 2011), amikor is a tudósok először osztották meg eredményeiket az olvasókkal a nyomtatott folyóiratokban. A nyílt tudomány egy későbbi forradalmáról a 2010-es évektől beszélhetünk, amikortól a tudósok az összes információt és tudást hozzáférhetővé tudják tenni, és ebből nekik is előnyük származhat. A nyílt tudomány megközelítését ugyanakkor már a kezdetektől fogva számos kritika érte. Ezek közül az egyik (Stodden, 2010) arra hívja fel a figyelmet, hogy a szükséges technológiai eszközök nem fejlődnek elég gyorsan, és ez hitelességi válsághoz vezethet. Megjelenik a generációs probléma is: a fiatalabb kutatók inkább motiváltak az információ megosztásában. Napjainkra már általánossá vált a nyílt tudománynak az eredetinél tágabb értelemben vett jelentése: az információ nem csupán a tudósok között, hanem a kutatói közösségen kívül is áramlik.

Ezzel összhangban van Michael Nielsen kvantumfizikus 2011-ben a nyílt tudományról tartott TED-előadása, melyben úgy fogalmazott: egyre nagyobb a tudósok felelőssége, hogy a tudományos felfedezéseket és ötleteket a kutatás minél korábbi fázisában megosszák, és nem csupán a kutatókkal, hanem a közönség teljes körével (Nielsen, 2011).

\subsection{A média szerepe}

A 2000-es évek eleje, a nyílt tudomány megjelenése óta jelentősen megváltozott a kutatók vélekedése az adat és a tudás terjesztéséről. Bár előnyei egyértelműek, számos módszer alkalmazása még mindig idegen számukra. Ezek erősen kötődnek a média megváltozott szerepéhez (Yeo-Brossard, 2017). A nyílt tudomány egyik előnye, hogy a kutatók sokkal akkurátusabbak, kétszer is ellenőrzik az eredményeiket, ha azok szabadon hozzáférhetők. A másik, hogy már a kutatási folyamat első lépéseként segíthet megkülönböztetni a hiedelmet a valós tényektől.

Az mindenesetre elfogadott, hogy a tudósoknak több előnyük származik abból, ha megosztják az eredményeiket a szélesebb közönséggel. Több lehetséges módja is van, hogy elkezdődjön a párbeszéd az érintett, szakmai és szakmán kívüli közönség között, elég csupán a közösségi médiában rejlő lehetőségekre gondolni: nem csupán az írott bejegyzésekre, hanem a videó- és képüzenetekre is. A bejegyzések és kommentek esetében nemcsak a közlőik, hanem az olvasók és a nézők is profitálnak belőlük. A publikációs folyamat legfőbb kontrollját továbbra is a folyóirat-szerkesztők és a szakcikkek bírálói, a kapuőrök jelentik. 
A megváltozott médiakörnyezetnek köszönhetően a tudósok és a közönség közötti kapcsolatok is átalakultak. A multimédia és közösségi média új technológiai környezete közvetlen és interaktív kommunikációs lehetőségeket kínál mindkét fél számára. A tudósok és a média kapcsolatát vizsgálva azt látjuk, hogy egészen a 2000-es évek közepéig nem voltak kiaknázva az ebben rejlö lehetőségek, sőt egyfajta negatív hatás is megfigyelhető volt. A kérdéssel foglalkozó kutatók (Yeo-Brossard, 2017) egyetértenek abban, hogy a közönséggel való kapcsolattartásra a tudósok körében az úgynevezett „Sagan-hatás” (Sagan effect) volt jellemző. Eszerint minél népszerübb lett egy tudós, annál inkább csökkent tudományos munkájának mennyisége, és vált gyengébbé annak minősége ${ }^{1}$ (Pagan, 2013). Az azóta eltelt évek alatt ez a felfogás jelentősen megváltozott.

Mitől függ a tudósok médiabeli aktivitása, különös tekintettel a demográfiai jellemzöikre és kutatási hatékonyságukra?

Az egyik jellemző befolyásoló tényező (Yeo-Brossard, 2017) a rendelkezésükre álló idő, egy másik pedig szakmabeli helyzetükkel van összefüggésben: minél inkább karrierközpontú és szakmailag aktívabb egy kutató, annál motiváltabb a közönségszereplésben. Korábbi tapasztalatai szintén pozitívan befolyásolják a média iránti nyitottságát. Pozitívan hatnak a tudós és a média kapcsolatára a kutató belső, morális jellemzői (elégedettség, a társadalmi felelősség érzete) vagy külső tényezők (szervezeti láthatóság) is. Az egyetemek és tudományos intézmények által kínált tudománykommunikációs tanfolyamok és tréningek sokat segíthetnek abban, hogy a kutatók otthonosabban viselkedjenek e téren.

\subsection{A civil társadalom által motivált tudományos felfedezés}

A nyílt tudomány szoros összefüggésben áll a „társadalom tudomány iránti elkötelezettségével”, ennek tükrében vizsgálható a társadalom bevonásának lehetősége a kutatási folyamatokba (Stodden, 2010).

A tudomány digitalizációjával egyre inkább elterjed és elfogadottá válik a tudományos módszerek és az adatok megosztása (beleértve a kódokat és szoftvercsomagokat is), ezzel pedig a tudományos kísérletek mások számára is hozzáférhetővé, akár megismételhetővé válnak, beleértve a tudományon kívüli közösséget is. Tehát a laikusoknak is lehetőségük lesz hozzájárulni az új tudományos felfedezésekhez. Önkéntes résztvevőként számos tudományos kutatási folyamat már most hozzáférhető a tudomány iránt érdeklődők számára (ilyen kezdeményezés például a DIYbio.org vagy a Zooniverse.org). Ezeknek a kezdeményezéseknek a lényege, hogy amatőr tudósoktól adatokat gyüjtsenek, és azokat tudományos

\footnotetext{
${ }^{1}$ A jelenséget Carl Sagan csillagászról nevezték el, aki ismeretterjesztő tevékenységéről vált híressé. Bővebben lásd Oné R. Pagan kutatói blogját (Pagan, 2013).
} 
célokra használják fel. Ezáltal a kutatási projektek rövidebb idő alatt elvégezhetők, sokkal nagyobb mennyiségü adat válik hozzáférhetővé, a civil kutatók (citizen-scientists) pedig a folyamat végén a publikációk társszerzőivé válhatnak. Az ilyen jellegü projektek segíthetik a kapuőröket is a tudományos tények megismerésében és meghatározásában.

Victoria Stodden hangsúlyozza, hogy a fenti modell számos tudományfilozófiai kérdést feszeget, például a tulajdonjogét. 1942-ben Robert Merton a tudományos tudás és a tudomány ethoszának megfogalmazásában - beleértve a négy mertoni normát (közösségiség, univerzalizmus, pártatlanság, szervezett szkepticizmus) nem foglalkozott a tulajdonjoggal. További kérdés, hogy mivel lehet ösztönözni a civil kutatókat. Akár a tudományos felfedezésekben való részvétel is ösztönző lehet számukra, de a tudományos publikációk és hivatkozások inkább a tudományos közösségnek jelentenek sikert, nem a civil lakosságnak.

\section{A TUDOMÁNYFELFOGÁS VÁLTOZÁSA}

Az 1990-es években, a tudománynépszerüsítés modern korszakának kezdetekor a hangsúly a tudomány megértésén volt. A hangsúly a befogadói oldalra helyezödött, melyet elsősorban kormányzati és tudománytechnológiai szempontok motiváltak (Stilgoe et al., 2014).

Az 1990-es években megjelenő „posztnormál” tudományos korszak a „normál tudomány" Thomas Kuhn az 1960-as években megfogalmazott elméletére reagált (Fehér, 2002). A jelenlegi, technológiavezérelt „posztnormál” tudomány résztvevői egyetértenek abban, hogy aktívabb részvételre és a laikusok, szakértők és döntéshozók közötti együttmüködésre van szükség. Krízishelyzet a tudomány reprodukálhatóságát, valamint a tudomány irányítását és a tudomány politikai célokra való felhasználását illetően alakult ki (Saltelli-Funtowitz, 2017). Az emberek nem bíznak a tudósok és intézményeik által előállított tudományos bizonyítékokban, a tudomány irányításában, továbbá kétségeik vannak az eredmények reprodukálhatósága felől (Saltelli-Funtowitz, 2017).

Napjaink tudósainak nem okoz nehézséget kapcsolatba kerülni a közönséggel, gondoljunk csak a kutatás során keletkező tudományos tudás online megosztására. A tudósok blogot írnak, ahol megosztják az információt és az élményeiket. Ez a kutatói nyitottság közelebb hozza a közönséget a kutatás különböző fázisaihoz. A tudományos blogot olvasók akár hozzá is járulhatnak a tudományos tudás előállításához: hozzászólásokkal, megjegyzésekkel bárki felvethet olyan új szempontot, amely inspirálhatja a szerzőt. A közösségi médiában való szereplés vágya ugyanakkor erősebbé is válhat a tudományos tartalomnál. A korábban említett Sagan-hatáshoz hasonló a Neil Hall (2014) által megfogalmazott, ún. „Kardashian-index”, mely a tudós Twitter-követőinek szá- 
mát mutatja tudományos hivatkozásainak függvényében. Hall a tudományos érték megőrzése érdekében azt javasolja, hogy ha egy kutató K-indexe túl magas, akkor nyilvánítsák a „tudomány Kardashianjának”, akinek ideje visszatérni a tudományos cikkek publikálásához.

\subsection{A deficittőll a párbeszédmodellig}

Sheila Jasanoff (2014) kiemeli, hogy az 1990-es évek elején jellemző, „deficitjellegü" tudománykommunikációs módszerek egyirányúak voltak. A kommunikációs folyamat során a tudományos tudást birtokló fél megpróbálta odairányítani az információt, ahol arra a legnagyobb szükség volt. A tudománykommunikációs szakemberek - az üzleti szféra szereplöihez hasonlóan - erre irányuló kampányokat hirdettek. A meghatározott célcsoportnak a leghatékonyabb csatornán keresztül juttatták el - egy irányban - az információt, a közönség pedig passzívan viselkedett. Ennek eredményeképp torzult a tudományról alkotott kép, erősödtek a tudósokról alkotott sztereotípiák (férfi kutatók, akik érthetetlen tudományt müvelnek, és érzéketlenek a társadalmi folyamatok iránt).

$\mathrm{Az}$ újraértelmezett tudományfelfogási modellben (public understanding of science) a tudósok és a döntéshozók is részesei a folyamatnak, a tudomány a társadalom részeként jelenik meg. Meghaladottá vált az a felfogás, mely szerint a tudománykommunikáció csupán áthidalja a laboratórium és a tudományt elutasító közönség közötti szakadékot. A tudomány megértése több egy egyszerü folyamatnál (Jasanoff, 2014), az információ befogadójának igénye van arra, hogy átfogóan meg is értse a tudományos tudást - ennek következtében a tudománykommunikációs szakterület felfogása megváltozott. A közösség problémaorientált, és hozzá is járul a tudás előállításához. A folyamatban a hangsúly a tudomány bemutatásán (representation of science) és nem annak egy irányban történő megértetésén van. A hagyományos és formális tudománykommunikációs csatornák (például tudományos konferenciák) egyre több informális elemmel (tudományos kávézók, múzeumok és tudományos központok), valamint a közösségi konzultáció lehetőségével egészülnek ki.

\section{ESETTANULMÁNY - FILMKLUB AZ AKADÉMIÁN}

Az esettanulmányban bemutatott Filmklub az Akadémián kezdeményezés jó példa lehet a fent említett informális tanulási és tudománykommunikációs lehetőségek gyakorlatban történő alkalmazására, erősítve a valódi tudomány bemutatását, és kezelve az ,igazságon túli” környezetből fakadó nehézségeket.

A Magyar Tudományos Akadémia változatlanul kiemelkedő közbizalomnak örvend a lakosság körében. A helyszín egyfajta garanciát jelent a megszólaló tu- 
dósok és a bemutatott tudományos eredmények hitelességére. Egy olyan közönségbarát müfajjal, mint a tudományos-ismeretterjesztő film, igen széles körben sikerül megszólítani az embereket. A fiatalabb és idősebb generációnak egyaránt tanulási lehetőséget jelent egy-egy vetítés, mely minden alkalommal szakértöi beszélgetéssel zárul. Az évekkel ezelőtt indított programsorozatra 2019 májusáig több mint ötezren regisztráltak. A nézők körében felmérést végeztem a tudományos tudásra vonatkozó fogyasztási szokásaikról, a kiküldött kérdőívekre közel ötszáz válasz érkezett 2018 májusa és júniusa között.

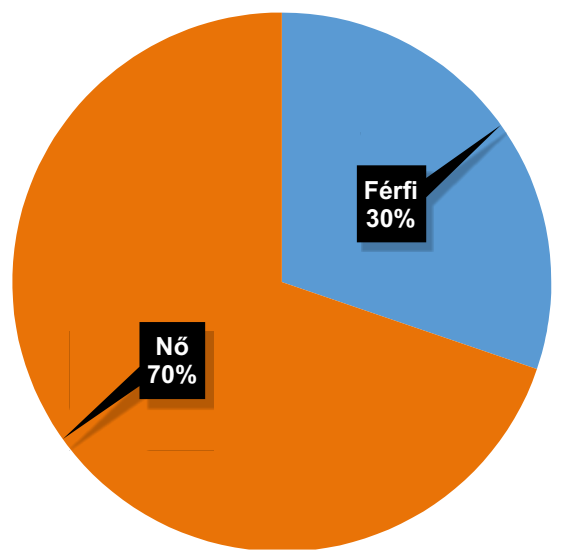

1. ábra. A résztvevők megoszlása nemek szerint

(Az összes ábra a szerző saját szerkesztése)

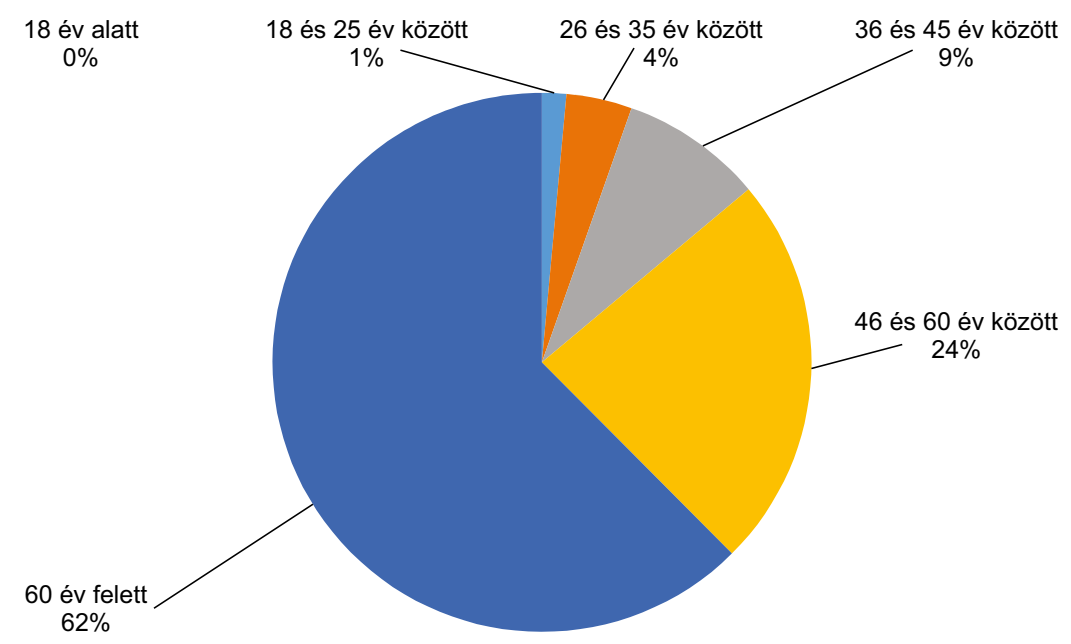

2. ábra. A résztvevők megoszlása életkor szerint 


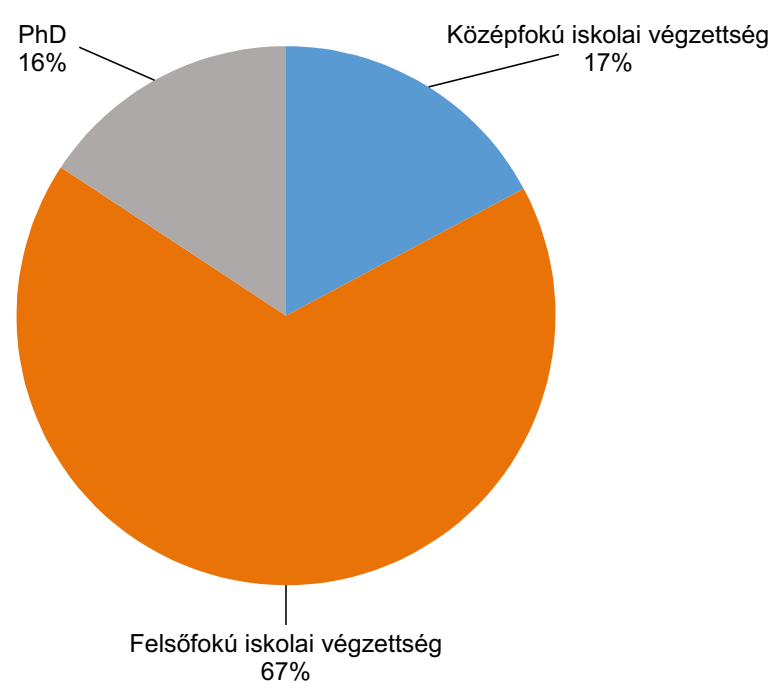

3. ábra. A résztvevők megoszlása iskolai végzettség szerint

Az 1-3. ábrák jól mutatják, hogy a vetítésekre elsősorban hatvan év feletti, felsőfokú végzettségü hölgy résztvevők jelentkeznek, jóllehet minden témának megvan a fiatalabb résztvevői közönsége is. Ez összefüggésben lehet a program időzítésével (hétköznap délután). Arra a kérdésre, hogy honnan hallottak az eseményről, a résztvevők jelentős része (20\%) azt válaszolta, hogy ismerős vagy családtag ajánlotta, illetve más informális csatornán hallott róla. Még magasabb azok aránya (35\%), akik az interneten, elsősorban a Facebookon keresztül értesültek a sorozatról. Érdemes megemlíteni néhány választ arra a kérdésre, hogy miért látogattak el az eseményre: „Azért, mert az Akadémia garanciát jelent az információ hitelességére”; „Hogy specifikus, máshonnan meg nem szerezhető ismeretekhez jussak a magyar tudósok különböző tudományos projektekben való részvételéről és szerepéről”; „Érdekelnek a témák és utána a beszélgetés”; „Világos és közérthető”; „Sokat lehet tanulni belőle”; „Érdekes témákról objektív, tényszerű feldolgozásokat láthatok". A válaszok kellőképpen reprezentálják azt a korábbi feltevést, hogy a sikeres tudománykommunikáció legyen interaktív, objektív, közérthető, egyértelmü, és valódi tudományt mutasson be.

Az 5. és 6. ábra eltérését érdemes megnézni. Annak ellenére, hogy szinte valamennyi résztvevő (92\%) érdeklődik a vetítés utáni beszélgetés iránt, csupán 21 százalékban válaszolták azt, hogy biztosan kérdeznének is a jelen lévő kutatótól. Legnagyobb a bizonytalanok aránya (70\%), akik a témától függően esetleg kérdeznének. Ez következhet abból is, hogy a szakmán kívüliek bizonytalanok abban, hogy tudnának-e releváns kérdést feltenni a jelen lévő tudósnak. 


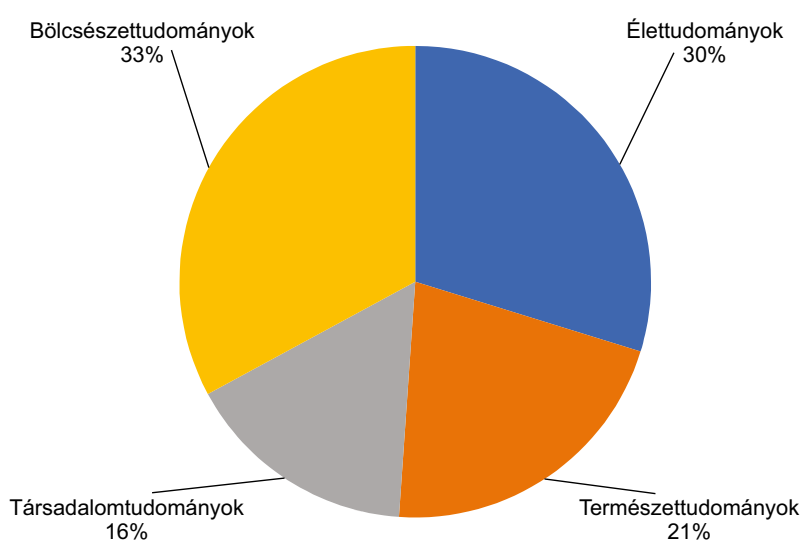

4. ábra. A tudományterületek iránti érdeklődés megoszlása

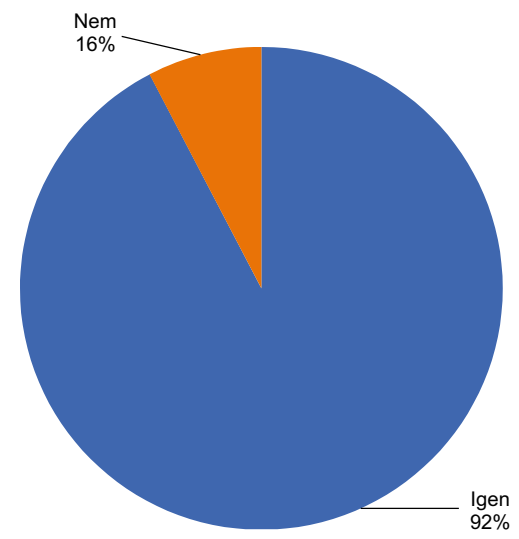

5. ábra. Érdeklik a beszélgetések a vetítések után?

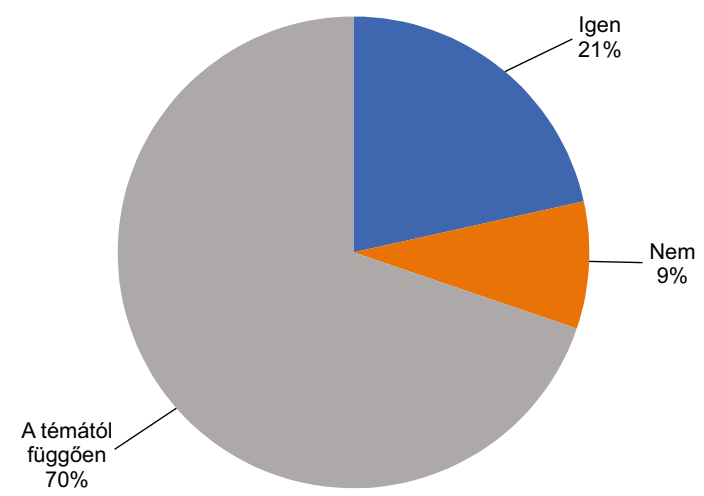

6. ábra. Kérdezne a kutatótól a vetítés után? 


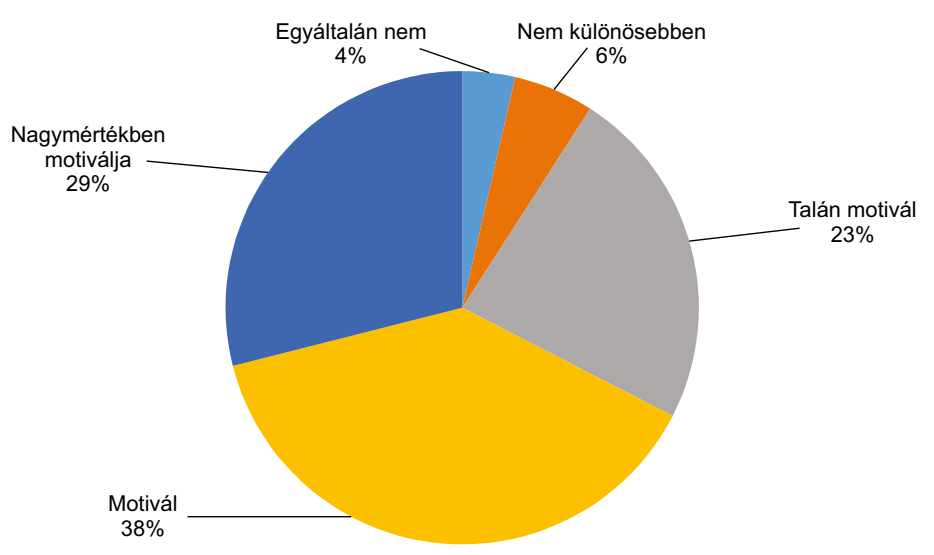

7. ábra. A helyszín mennyire motiválja a részvételét?

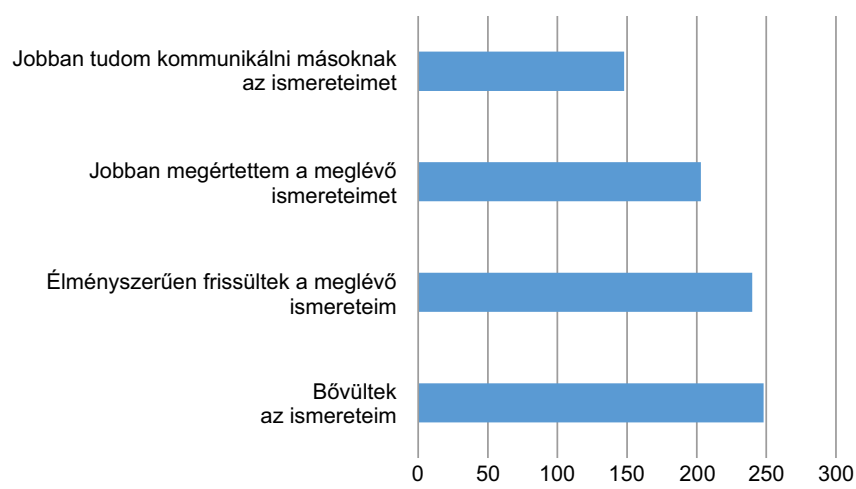

8. ábra. Bővült-e a tudása az esemény végére? (válaszok száma)

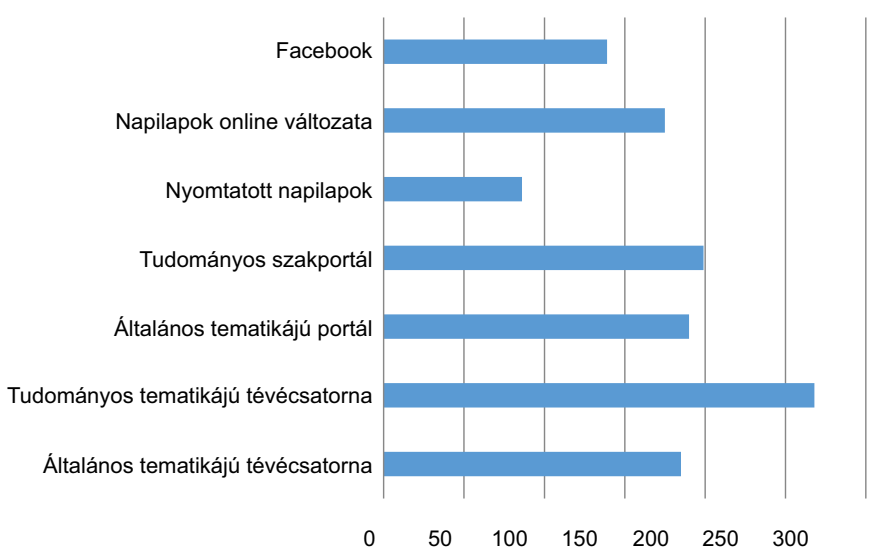

9. ábra. Honnan értesül a tudományos hírekről? (válaszok száma) 
A 7-9. ábrákból látszik, hogy a helyszín kiemelten fontos motivációs tényező az esemény látogatásában, mely erösítheti az információforrás hitelességét. A résztvevők többségének bővült a tudása az esemény végére: legföképp az adott tudományágat illetően javultak a kommunikációs készségeik, illetve frissültek a meglévő ismereteik. A 9. ábrán látszik, hogy a válaszadók többségének az elsődleges hírforrást továbbra is a tudományos televíziós csatornák jelentik, jóllehet a közösségi média és az internet egyre erősebb mértékben van jelen.

\section{KONKLÚZIÓK}

Napjaink tudománykommunikációs folyamata többszereplős (Wingens et al., 2018): a média vagy a civil társadalom éppúgy érintett, mint az ipari szereplők. Sajnos a tapasztalat azt mutatja, hogy a kutatók még mindig nem elég motiváltak a közösség bevonásában és a tudomány kifelé történő kommunikációjában, ezért interaktívabb, párbeszédközpontú kezdeményezések szükségesek, melyben a felek együttmüködnek.

A nyomtatott sajtó és az online cikkek mellett az informális csatornák (science cafék, tudományos beszélgetések) számának növekedésével egyre nő a lehetőség a fenti kapcsolat bővítésére. Ehhez megfelelő hátteret jelenthet a kutatók számára a nyílt tudomány, amelyben a csatornák bővülésével egyre szélesebb körhöz juthat el a tudományos információ. Ugyanakkor ez némi kockázatot is hordozhat magában: tudományellenes szempontok terjedhetnek el, és az alternatív valóságok veszélyeztetik az adott területen a tudományos konszenzust.

Hogyan lehet felismerni a tudományellenes tényeket? Mit nevezünk valódi tudománynak? A tudományban való együttmüködés összetett folyamatában garanciák és hiteles kapuőrök szükségesek: e téren továbbra is a tudományos intézmények, hiteles kutatóhelyek, egyetemek, valamint a hiteles kiadók, szerkesztőbizottságok és szakértői értékelések bizonyulnak a legmegbízhatóbbnak.

A bizonytalanság ellenére továbbra is erős a tudományba vetett bizalom. A tudósokban megbízunk a szakértelmük miatt. További, kevésbé hangsúlyozott bizalmi tényező a tudósok erkölcsi hitelessége. Egy tudósban annál jobban bízunk, minél őszintébb, objektívabb, és minél inkább követi a tudományos normákat. Ugyanakkor hozzátartozik, hogy határolódjon el a tudomány szabályainak megszegésétől, mint például a plagizálástól vagy az adathamisítástól.

A tudományos tényeket kellőképp hangsúlyozni kell, kihasználva a média nyújtotta csatornákat - ez jelenti a legnagyobb kihívást napjaink tudománykommunikációs szereplöinek. Nyílt és tudományközpontú párbeszédre van szükség, melyben a közönség értesülhet a bizonytalanságokról és a tudomány korlátairól is. Az érintett feleknek társadalmi, kulturális és etikai szempontok figyelembevételével kell együttmüködniük. A jó példák bemutatása segíthet ennek elmélyítésében. 


\section{IRODALOM}

Chen, Y. - Conroy, N. J. - Rubin, V. L. (2015): Misleading Online Content: Recognizing Clickbait As "False News". In: WMDD '15. Proceedings of the 2015 ACM on Workshop on Multimodal Deception Detection. New York, NY, USA: ACM, 15-19. DOI: 10.1145/2823465.2823467, https://www.researchgate.net/publication/283721117_Misleading_Online_Content_Recognizing_Clickbait_as_False_News

Delfanti, A. (2010): Open Science, a Complex Movement. Journal of Science Communication, 09, 03, 1-2. DOI: 10.22323/2.09030501, https://jcom.sissa.it/sites/default/files/documents/ Jcom0903\%282010\%29E.pdf

Fehér M. (2002): Tudományról és tudományfilozófiáról az ezredfordulón. Magyar Tudomány, 3, 297-305. http://www.matud.iif.hu/02mar/feher.html

Hall, N. (2014): The Kardashian Index: A Measure of Discrepant Social Media Profile for Scientists. Genome Biology, 15, 7, Nr. 424. DOI: 10.1186/s13059-014-0424-0, https://genomebiology. biomedcentral.com/articles/10.1186/s13059-014-0424-0

Heuer R. (2017): A Science-based Advice to Policy-makers in an Era of Alternative Facts. World Science Forum 2017 Jordan. Day 2 porgram: https://2017.worldscienceforum.org/programme/ 2017-11-08-iii-a-science-based-advice-to-policy-makers-in-an-era-of-alternative-facts-19, video (Rolf Heuer az altenatív tényekről 31:30-től): https://youtu.be/gNkXMQtwerk

Jamieson, K. H. - Kahan, D. M. - Scheufele, D. A. (eds.) (2017): The Oxford Handbook of the Science of Science Communication. Oxford University Press

Jasanoff, S. (2014): A Mirror for Science. Public Understanding of Science, 23, 1, 21-26. DOI: $10.1177 / 0963662513505509$.

Lynch, M. (2017): STS, Symmetry and Post-truth. Social Studies of Science, 47, 4, 593-599. DOI: 10.1177/0306312717720308, https://www.researchgate.net/publication/319010583_STS_symmetry_and_post-truth

McIntyre, L. C. (2018): Post-truth. The MIT Press Essential Knowledge Series. Cambridge: MIT Press

Nielsen, M. (2011): Open Science. TEDxWaterloo előadás, https://youtu.be/DnWocYKqvhw, idézi: Dutcher, Jennifer (2014): Michael Nielsen: Open Science Now! Berkeley School of Information. https://datascience.berkeley.edu/michael-nielsen-open-science-now/

Oxford Dictionaries (2016): Word of the Year 2016 Is... https://languages.oup.com/word-of-theyear/word-of-the-year-2016

Pagan, O. R. (2013): The Sagan Effect. https://baldscientist.wordpress.com/2013/02/10/the-saganeffect/

Pariser, E. (2011): The Filter Bubble. What the Internet is Hiding from You. New York: The Penguin Press

Saltelli, A. - Funtowicz, S. (2017): What Is Science's Crisis Really About? Futures, 91, 5-11. DOI: 10.1016/j.futures.2017.05.010, https://www.sciencedirect.com/science/article/pii/S0016328 717301969

Sismondo, S. (2017): Post-truth? Social Studies of Science, 47, 1, 3-6. DOI: 10.1177/030631271769 2076, https://journals.sagepub.com/doi/full/10.1177/0306312717692076

Stilgoe, J. - Lock, S. J. - Wilsdon, J. (2014): Why Should We Promote Public Engagement with Science? Public Understanding of Science, 23, 1, 4-15. DOI: 10.1177/0963662513518154, https:// journals.sagepub.com/doi/10.1177/0963662513518154

Stodden, V. (2010): Open Science: Policy Implications for the Evolving Phenomenon of User-led Scientific Innovation. Journal of Science Communication, 09, 01, 1-8. https://jcom.sissa.it/sites/default/files/documents/Jcom0901\%282010\%29A05.pdf 
Wingens, M. - Ziegler, R. - Weisskopf, M. (2018): Science Communication in a Complex World. Discussions, Impulses and Results From Two Stakeholder Workshops. Wissenschaft im Dialog. https://www.wissenschaft-im-dialog.de/fileadmin/user_upload/Ueber_uns/WiD_dokumente/19_Konferenzbericht_Science_Communication_in_a_Complex_World.pdf

Yeo, S. K. - Brossard, D. (2017): The (Changing) Nature of Scientist-Media Interactions: A Crossnational Analysis. In: Jamieson, K. H. - Kahan, D. M. - Scheufele, D. A. (eds.): The Oxford Handbook of the Science of Science Communication. Oxford University Press, 261-272.

Zuiderveen Borgesius, F. - Trilling, D. - Moeller, J. et al. (2016): Should We Worry About Filter Bubbles? Internet Policy Review. Journal on Internet Regulation 5, 1, https://policyreview.info/ articles/analysis/should-we-worry-about-filter-bubbles 